\title{
New Approach of Integration: Integrative Hematology
}

\author{
Bonucci $\mathrm{M}^{1}$ and Andreazzoli $\mathrm{F}^{2}$ \\ ${ }^{1}$ Department of Outpatient Oncology, San feliciano Hospital, Rome, Italy \\ ${ }^{2}$ Department of Hematology, Versilia's Hospital,Viareggio, Italy
}

Corresponding author: Massimo Bonucci, Head of Department of Outpatient Oncology, San feliciano Hospital, Rome, Italy, Tel: +39 3394640532 ; Email: maxbonucci@artoi.it

Received Date: March 02, 2017; Accepted Date: March 10, 2017; Published Date: March 14, 2017

Copyright: (c) 2017 Bonucci M, et al. This is an open-access article distributed under the terms of the Creative Commons Attribution License, which permits unrestricted use, distribution, and reproduction in any medium, provided the original author and source are credited.

Citation: Bonucci M, Andreazzoli F. New approach of Integration: Integrative Hematology. Br J Res 2017, 4:6.

\section{Editorial on Integrative Hematology}

Integrative Oncology, as a specific field of integrative medicine, is a reality today. There are many references, abstracts and books which talk about it and even a medical association in the USA, the Society of Integrative Oncology which prove how this topic is now emerging.

In Italy as well, an Association called ARTOI (Associazione di Ricerca in Terapie Oncologiche Integrate) is deeply concerned with this part of medicine.

In the field of hematological malignancies no references or books can be found but for one citation about an integrated approach in hematological patients in an abstract which was presented for the first time at the Congress of American Society for Haematology in Atlanta in 2005 [1].

Since then, no further study has been provided.

We think, instead, for many reasons that Oncology and Hematology are two separate worlds which cannot be joined together.

Hematological tumors often originate from cells directly derived from the immune system; so, a deeper knowledge and manipulation of this system is required.

Many blood neoplasias have an indolent behavior like some types of Lymphoma whereas others have even a life expectancy which is only a little lower than that of healthy people as it happens with Essential Thrombocythemia [2-3].
For this reason specific natural substances could be really effective or could develop their pleiotropic activity in the long term.

The immune system is deeply involved in this type of disease, from diagnosis to treatment. So we need to know how it works, even to manipulate it in case of stem cell transplantation.

Therefore a deeper knowledge of this system is mandatory.

Integrative treatments in hematological patients are not well studied so far and clinical trials are still lacking; for instance, only 3 clinical trials have been made with curcumin, one of the most used remedies in Integrative Oncology.

We think that Integrative Hematology deserves its own space well distinguished from Integrative Oncology and that more detailed studies and clinical trials are needed for a better understanding of how to deal with these patients.

\section{References}

1. Kotouèek P, Sakalová A, Fábryová V (2012) Integrative hematology-new therapeutical approach in medicine. Lekársky obzor 61: 431-433.

2. Tefferi A (2012) Polycythemia vera and essential thrombocythemia: 2012 update on diagnosis, risk stratification, and management. Am J Hematol 87: 285-293.

3. Tefferi A, Barbui T (2017) Polycythemia vera and essential thrombocythemia: 2017 update on diagnosis, risk-stratification, and management. Am J Hematol 92: 94-108. 